\title{
PERANCANGAN DAN PENGEMBANGAN SISTEM INFORMASI PENJUALAN SPAREPART KOMPUTER BERBASIS WEB
}

\author{
Dedek Riswanto ${ }^{1)}$, Sifa Fauziah ${ }^{2)}$ \\ 1,2 Program Studi Sistem Informasi Akuntansi, Fakultas Teknik dan Informatika, \\ Universitas Bina Sarana Informatika \\ Co Responden Email: dede.akifa@gmail.com1
}

Article history

Received Des 31, 2020

Revised Feb 02, 2021

Accepted Feb 12, 2021

Available online Feb 27, 2021

Keywords

Design, development, sales, web

\footnotetext{
Riwayat

Diterima 31 Des 2020

Revisi 02 Feb 2021

Disetujui 12 Feb 2021

Terbit 27 Feb 2021

Kata Kunci

Perancangan, pengembangan, penjualan, web
}

\section{Abstract}

The design and development of a web-based computer spare part sales information system is an information system used for the sales process of computer spare parts at Yellow Computer. This web-based computer spare part sales information system is carried out by the admin and customers to facilitate sales transactions, create sales reports and expand product promotions. The system development method that I use in designing and developing a web-based computer spare part sales system on Yellow Computer uses the Software Development Life Cycle (SDLC) system development method. Whereas in the system testing method using blackbox testing. The author in developing a web-based computer spare parts sales information system using the programming language PHP, CSS, and MySQL, and the programming technique used is structured programming techniques.

\begin{abstract}
Abstrak
Perancangan dan pengembangan sistem informasi penjualan sparepart komputer berbasis web adalah sistem informasi yang digunakan untuk proses penjualan sparepart computer pada Yellow Computer. Sistem informasi penjualan sparepart computer berbasis web ini di lakukan oleh admin dan pelanggan untuk mempermudah dalam transaksi penjualan, pembuatan laporan penjualan serta memperluas promosi produk. Metode pengembangan sistem yang penulis gunakan dalam perancangan dan pengembangan sistem penjualan sparepart komputer berbasis web pada Yellow Computer menggunakan metode pengembangan sistem Software Development Life Cycle (SDLC). Sedangkan dalam metode pengujian sistem menggunakan pengujian blackbox testing. Penulis dalam mengembangan sistem informasi penjualan sparepart komputer berbasis web menggunakan bahasa pemrograman PHP, CSS, dan MySQL,dan teknik pemrograman yang digunakan adalah teknik pemrograman terstruktur.
\end{abstract}

\section{PENDAHULUAN}

Teknologi sekarang sudah merupakan salah satu bidang yang mengalami perkembangan sangat cepat. Telah banyak sektor yang menerapkan teknologi ini, salah satunya dalam bidang perdagangan. Lalu muncul perdagangan dengan internet sebagai sarana utama, yaitu $e$ commerce Implementasi e-commerce dalam dunia bisnis salah satunya adalah dengan banyak bermunculan situs-situs penjualan secara online atau berbasis web (Kaafi \& Syahriani, 2016). Menurut (Heldiansyah \& Rahma Indera, 2015) pada saat ini sistem penjualan dan promosi produk melalui internet sedang berkembang pesat. 
Sistem penjualan yang berlangsung saat ini di Yellow Computer yaitu setiap pembeli harus datang langsung ke toko untuk melakukan kegiatan transaksi pembelian sparepart komputer. Hal ini berakibat terhadap ketidakefisienan jumlah biaya yang relatif besar dan waktu serta tempat yang terbatas. Selain itu, penyimpanan nota penjualan juga belum terorganisir dengan baik sehingga memungkinkan hilangnya data-data transaksi penjualan. Proses pembuatan laporan penjualan akan terhambat karena kasir harus merekap satu per satu nota penjualan. Serta proses promosi masih belum maksimal dikarenakan pelanggan tidak bisa mengakses produk setiap saat sehingga produk belum dikenal oleh masyarakat luas. Maka perlu adanya suatu sistem penjualan berbasis web (e-commerce) untuk memudahkan promosi barang dan mempercepat proses transaksi jual beli.

Sedangkan untuk menjalankan proses bisnis ini membutuhkan sebuah sistem informasi yang terintegrasi dan online serta real time untuk menjalankan proses bisnis ini (Narindro \& Maya Topani, 2017). Kepuasaan pelanggan adalah suatu hal yang penting bagi perusahaan dapat meningkatkan kualitas pelayanan yang memberikan dampak positif agar usaha dapat berjalan (Septarini \& Husain, 2019)

Berdasarkan uraian diatas bahwa sistem informasi penjualan berbasis web (Ecommerce) sangat diperlukan pada Yellow Computer untuk mempermudah dalam transaksi penjualan, pembuatan laporan penjualan serta memperluas promosi produk.

\section{KAJIAN LITERATUR}

Menurut (Anna, Nurmalasari, \& Yusnita, 2018) Sistem adalah sekumpulan elemen, komponen atau subsistem yang saling berhubungan, bekerja sama dan membentuk satu kesatuan dalam upaya mecapai tujuan".

Informasi menurut (Setiawan \& Rostianingsih, 2020) adalah "data yang diolah menjadi bentuk yang lebih berguna dan lebih berarti bagi yang menerimanya, sedangkan data merupakan sumber informasi yang menggambarkan suatu kejadian nyata.

Website merupakan kumpulan halaman-halaman yang berisi informasi yang disimpan diinternet yang bisa diakses atau dilihat melalui jaringan internet pada perangkatperangkat yang bisa mengakses internet itu sendiri seperti komputer (Hastanti, Eka, Indah, \& Wardati, 2015).

\section{METODE PENELITIAN}

Metode penelitian yang digunakan untuk memperoleh data dan informasi yang diperlukan dalam perancangan dan pengembangan sistem penjualan sparepart komputer berbasis web pada Yellow Computer adalah :

\section{A. Metode Pengumpulan Data}

- Observasi

Penulis melakukan pengamatan langsung serta mengamati setiap proses yang terjadi dalam sistem penjualan yang berjalan pada Yellow Computer. Dari hasil observasi penulis mendapatkan data-data barang, data konsumen, data pembayaran, dan laporan penjualan.

- Wawancara

Penulis melakukan tanya jawab secara langsung untuk mendapatkan informasi mengenai proses penjualan yang ada pada Yellow Computer kepada Aji sebagai bagian penjualan dan Nurul Huda sebagai pemilik usaha mengenai proses penjualan yang ada pada Yellow Computer mulai dari proses pemesanan produk, proses pembayaran sampai proses pelaporan penjualan yang akan diserahkan kepada pemilik.

- Studi Pustaka

Penulis mengumpulkan materi-materi penelitian dengan menggunakan dan mempelajari berbagai macam buku maupun literatur yang berhubungan dengan penulisan penelitian ini tentang penjualan berbasis web. 


\section{B. Metode Pengembangan Sistem}

Metode pengembangan sistem yang penulis gunakan dalam perancangan dan pengembangan sistem penjualan sparepart komputer berbasis web pada Yellow Computer menggunakan metode pengembangan sistem Software Development Life Cycle (SDLC), yaitu :

- Analisa Kebutuhan Sistem

Tahap ini penulis mempelajari sistem web untuk menentukan antar muka, kebutuhan data, kebutuhan fungsional yang diperlukan dan sebagai solusi software yang dibutuhkan dalam pengembangan sistem yang akan dibuat. Dalam tahap pengembangan sistem yang akan penulis buat, penulis membutuhkan beberapa software yaitu sublime dan Xampp dengan menggunakan bahasa pemrograman PHP.

- Desain

Tahap desain database dirancang menggunakan diagram Entity Relationship Diagram (ERD), software architactury menggunakan UML (Undifined Modeling Language), dan untuk mendesain user interface menggunakan CSS (Cascading Style Sheet).

- Code Generation

Pada tahap ini penulis menggunakan bahasa pemrograman PHP, CSS, dan MySQL, teknik pemrograman yang digunakan adalah teknik pemrograman terstruktur.

- Testing

Pada tahap ini, penulis menggunakan evaluasi web sistem informasi penjualan penjualan sparepart komputer berbasis web dengan menggunakan penggujian blackbox testing.

- Support
Dalam pengembangan sistem informasi penjualan penjualan sparepart komputer berbasis web dibutuhkan server untuk hosting aplikasi web, domain untuk alamat URL, dan menggunakan software pendukung lainnya antara lain (Sublime, PHP dan Mysql).

Ruang lingkup yang menjadi pembahasan penelitian ini yaitu tentang penjualan sparepart komputer berbasis web dimulai dari proses penjualan dalam penulisan penelitian ini adalah dari Admin melakukan input data nama-nama barang yang tersedia serta verifikasi pemesanan yang telah dilakukan oleh pelanggan. Admin juga mencetak laporan penjualan dan laporan penerimaan kas setiap bulannya kepada pemilik toko. Pelanggan akan melakukan proses pendaftaran sebagai member. Setelah pelanggan menjadi member, pelanggan bisa melakukan proses order barang, pelanggan menentukan nama barang dan jumlah barang, lalu pelanggan akan melakukan pembayaran dan mengunggah bukti pembayaran.

\section{HASIL DAN PEMBAHASAN}

Setelah penulis melakukan obeservasi pada prosedur sistem berjalan penjualan sparepart computer pada Yellow Computer Permasalahan yang ada di dalam sistem penjualan di Yellow Computer adalah Pembuatan nota pembayaran masih secara manual dengan menulis daftar dan harga barang, sistem yang belum terkomputerisasi dapat menghambat dan memperlambat dalam proses pembuatan laporan penjualan barang, promosi produk yang kurang maksimal karena hanya terfokus pada satu wilayah saja.

Alternatif pemecahan masalah yang ditawarkan untuk menyelesaikan permasalahan yang ada pada Yellow Computer adalah dengan menerapkan sistem yang telah terkomputerisasi berbasis web sehingga lebih mudah dalam melihat data penjualan tanpa merekap nota pembayaran, dengan mengoptimalkan perancangan sistem penjualan dengan menggunakan komputer yaitu dengan menggunakan website yang dapat 
mempermudah proses penjualan dan pembuatan laporan penjualan sehingga mencegah terjadinya kehilangan banyak dokumen transaksi, dan dengan menggunakan sistem penjualan berbasis web sehingga bisa diakses oleh pelanggan yang ada di wilayah Depok maupun di wilayah luar Depok.

\section{A. Analisa Kebutuhan Software \\ 1. Tahapan Analisis}

Dari hasil analisa yang telah dilakukan pada Yellow Computer maka penulis telah merancang suatu sistem informasi dan media yang dapat menyelesaikan masalah tersebut. Adapun spesifikasi kebutuhan (System Requirement) adalah:

Halaman Admin :

A1. Admin login

A2. Admin mengelola data produk

A3. Admin mengelola data persediaan produk

A4. Admin mengelola pesanan produk

A5. Admin mengelola laporan penjualan produk

A6. Admin melihat data member

A7. Admin mengelola data pengiriman

A8. Admin mengelola data karyawan

Halaman Pelanggan :

B1. Pelanggan melakukan sign up

B2. Pelanggan melakukan sign in

B3. Pelanggan melihat produk

B4. Pelanggan memilih produk

B5. Pelanggan memesan produk

B6. Pelanggan melakukan pembayaran

B7. Pelanggan upload bukti pembayaran

\section{Usecase Diagram}

\section{a. Usecase Diagram User Admin}

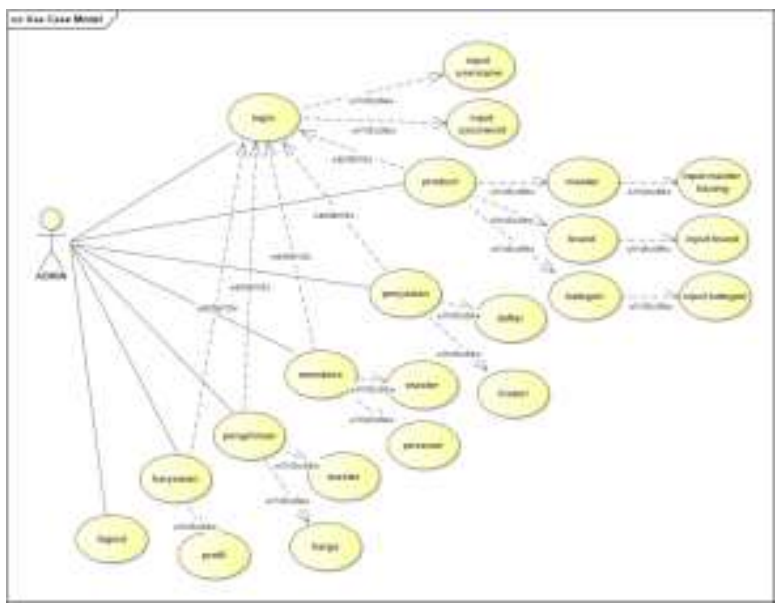

Gambar 1. Usecase Diagram Admin

\section{b. Usecase Diagram User Pelanggan}

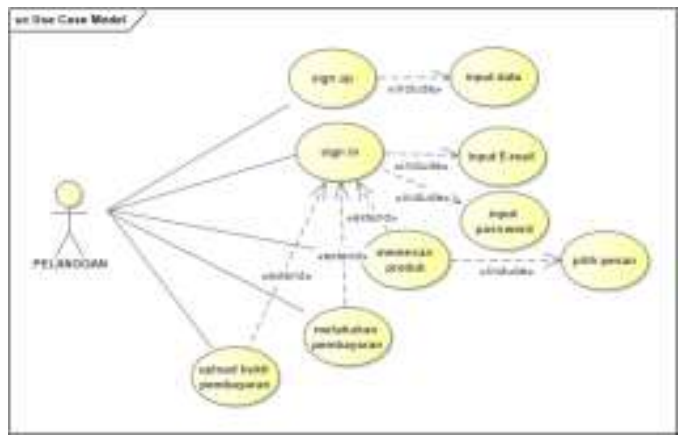

Gambar 2. Usecase Diagram User Pelanggan

3. Acivity Diagram

a. Activity Diagram pelanggan melakukan pemesanan

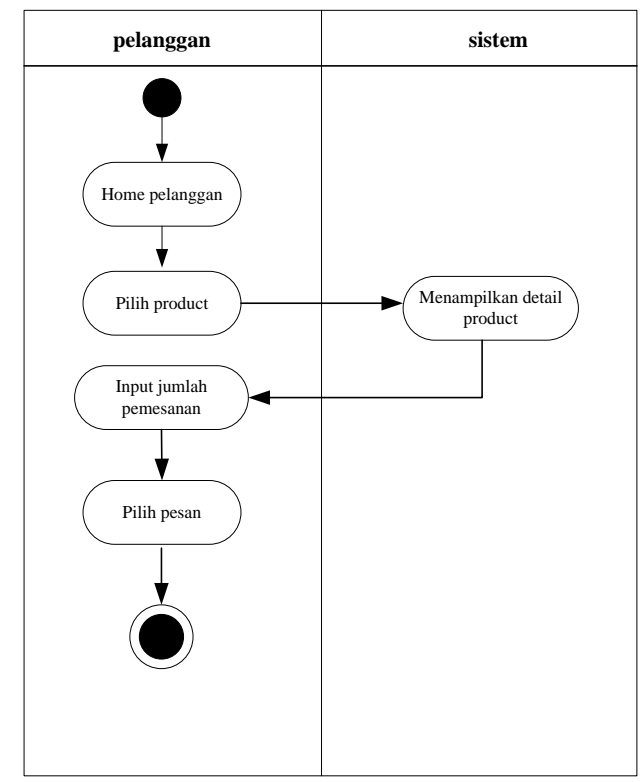

Gambar 1. Activity Diagram pelanggan melakukan pemesanan 
b. Activity Diagram pelanggan melakukan pembayaran

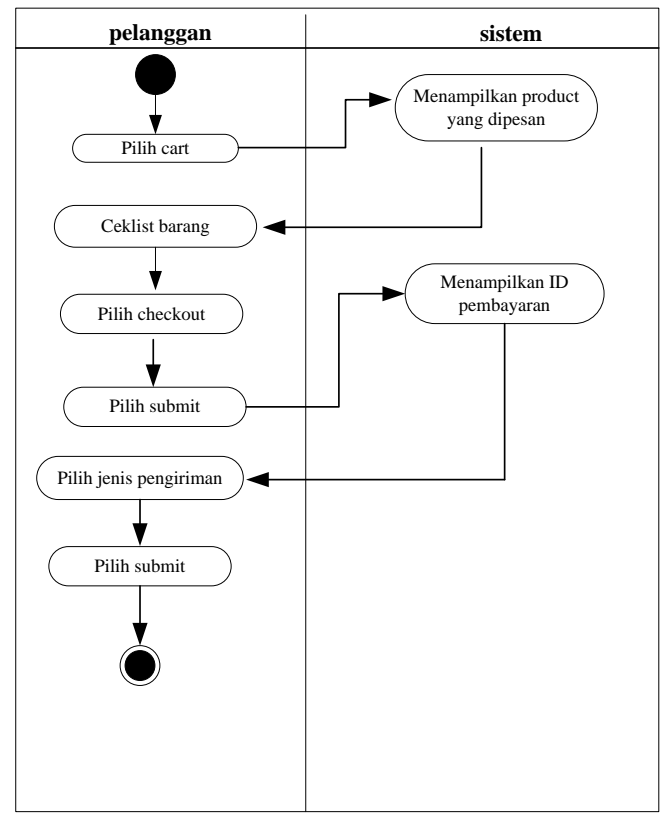

Gambar 2. Activity Diagram pelanggan melakukan pembayaran

\section{c. Activity Diagram pelanggan upload bukti pembayaran}

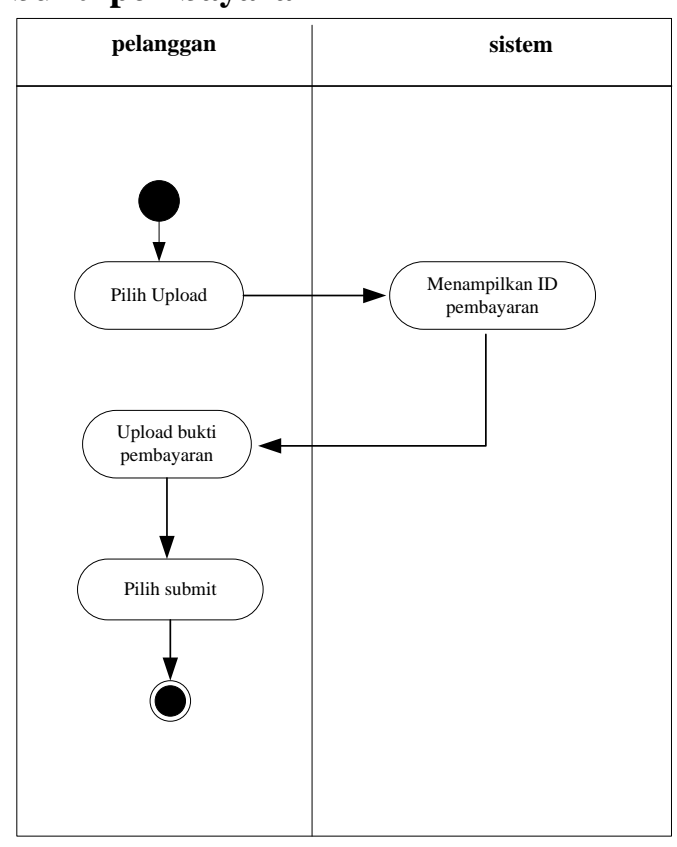

Gambar 3. Activity Diagram pelanggan upload bukti pembayaran

\section{d. Activity Diagram Admin menambah data produk}

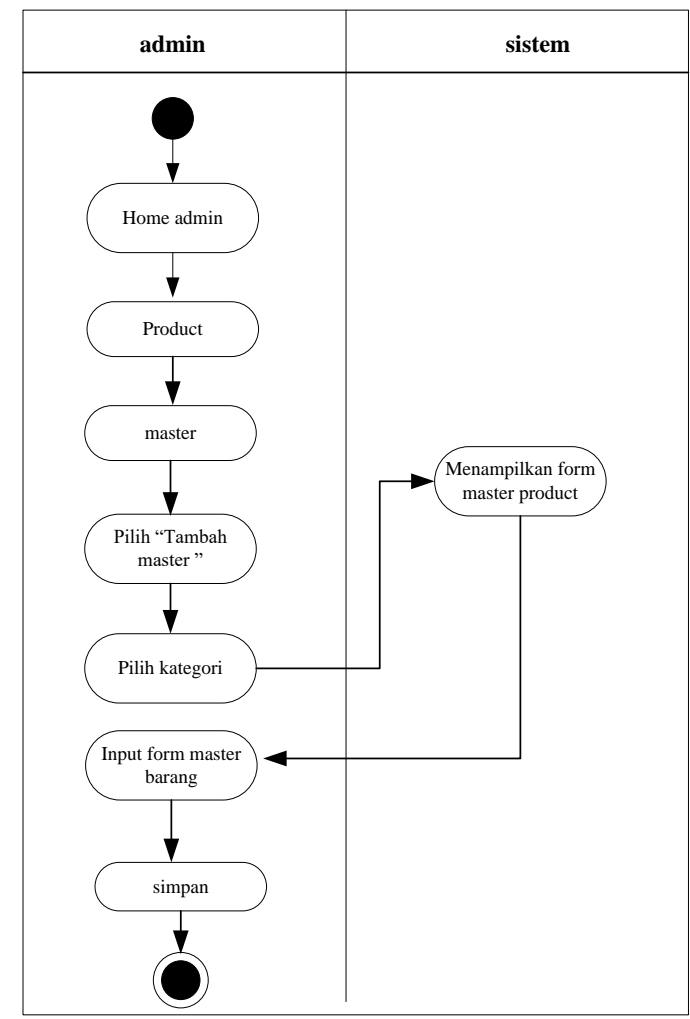

Gambar 4. Activity Diagram Admin menambah data produk

\section{e. Activity \\ Diagram \\ Admin} mengkonfirmasi data pesanan

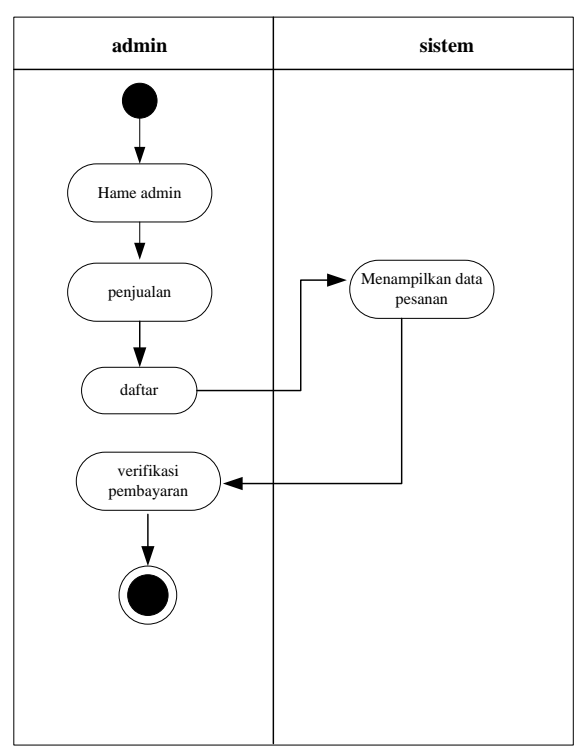


Gambar 5. Activity Diagram Admin mengkonfirmasi data pesanan

\section{f. Activity Diagram Admin mencetak laporan penjualan}

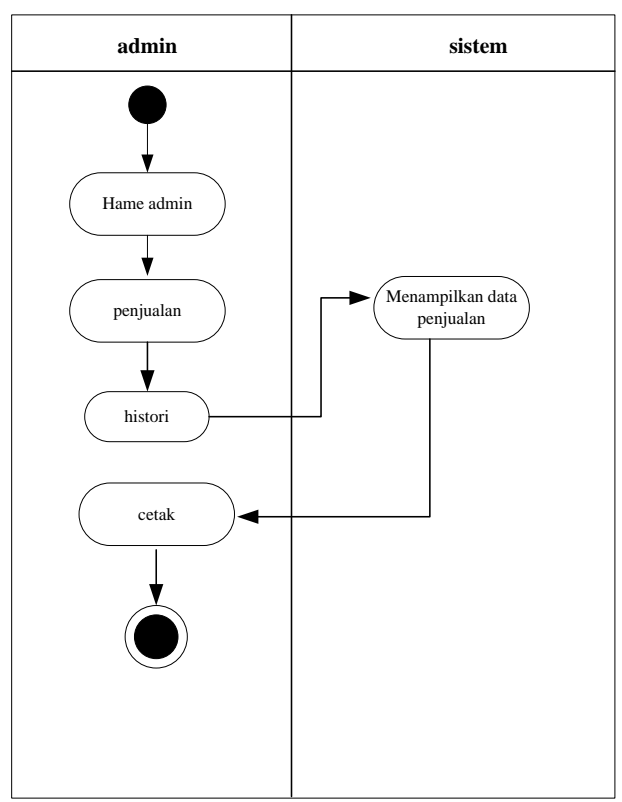

Gambar 6. Activity Diagram Admin mencetak laporan penjualan

4. Desain

a. ERD (Entity Relationship Diagram)

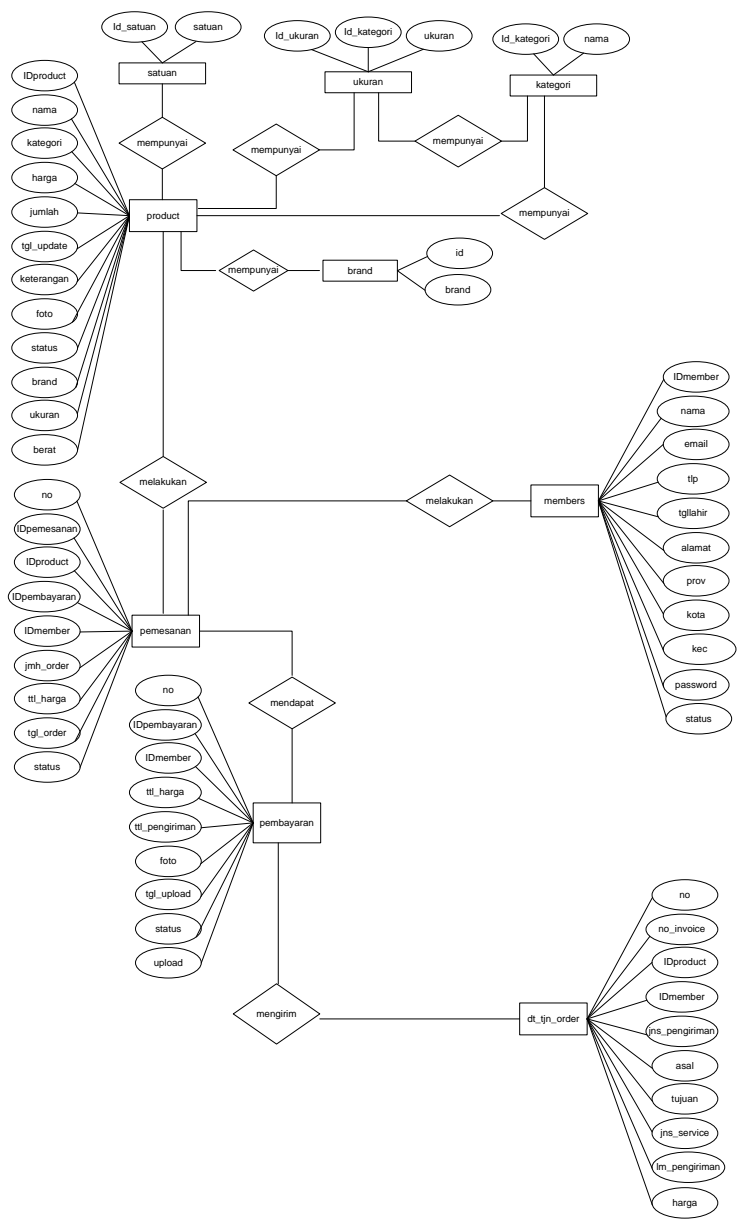

Gambar 7. Entity Relationship Diagram

\section{b. LRS (Logical Record Structure)}

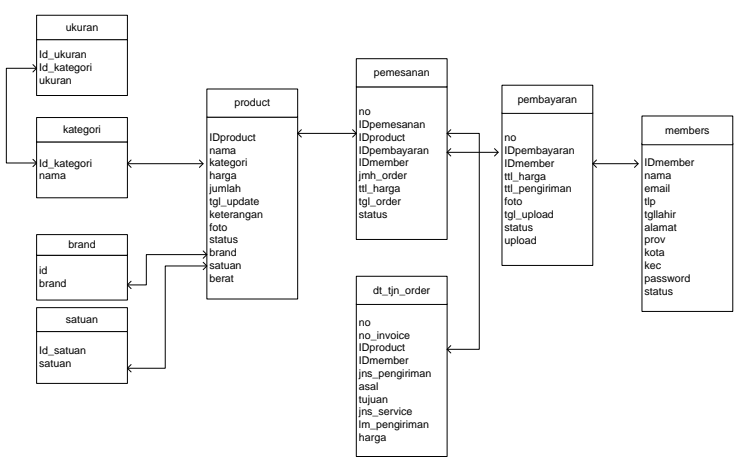

Gambar 8. Logical Record Structure

c. Sequence Diagram 


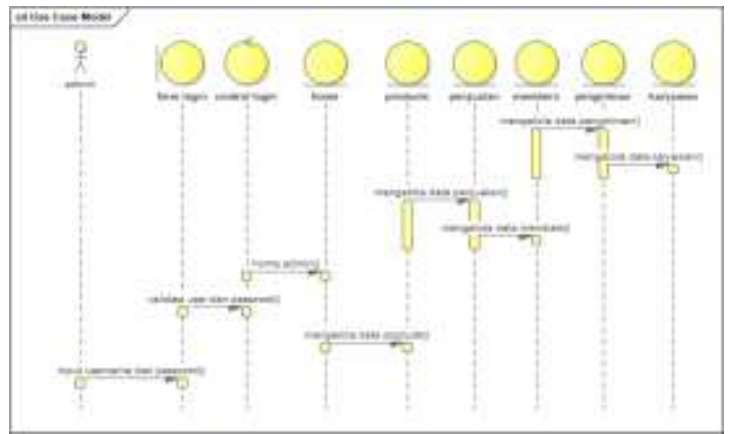

Gambar 9. Sequence Diagram

d. Deployment Diagram

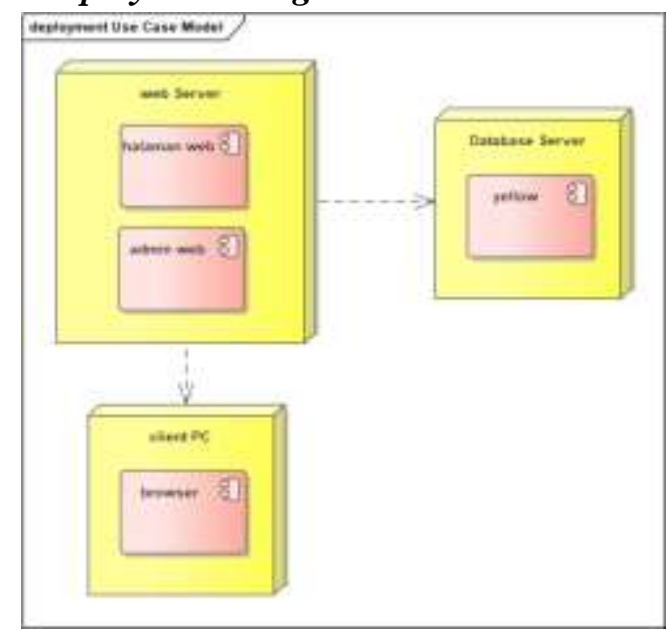

Gambar 10. Deployment Diagram

\section{User Interface}

Berikut ini adalah tampilan dari pengembangan sistem informasi penjualan computer berbasis web pada Yellow Computer:

a. Halaman Login

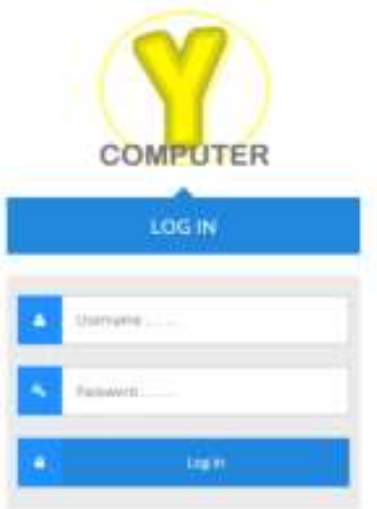

Gambar 11. Halaman Login

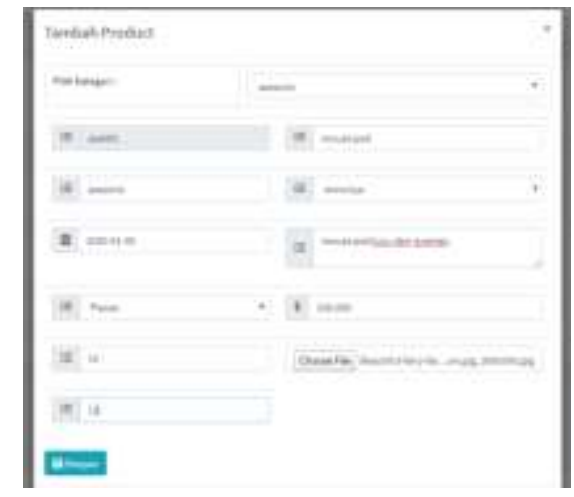

Gambar 12. Halaman Data Produk

c. Halaman mengolah data pemesanan

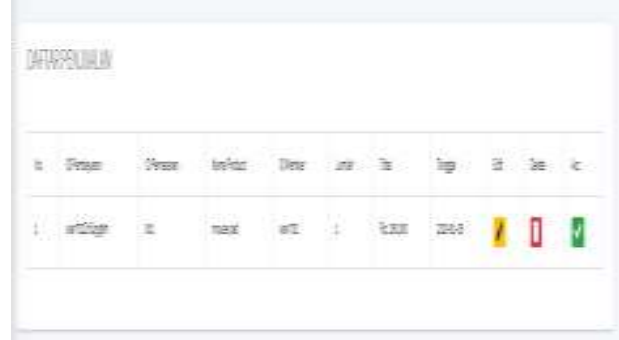

Gambar 13. Halaman mengolah data Pemesanan

d. Gambar admin melihat laporan penjualan

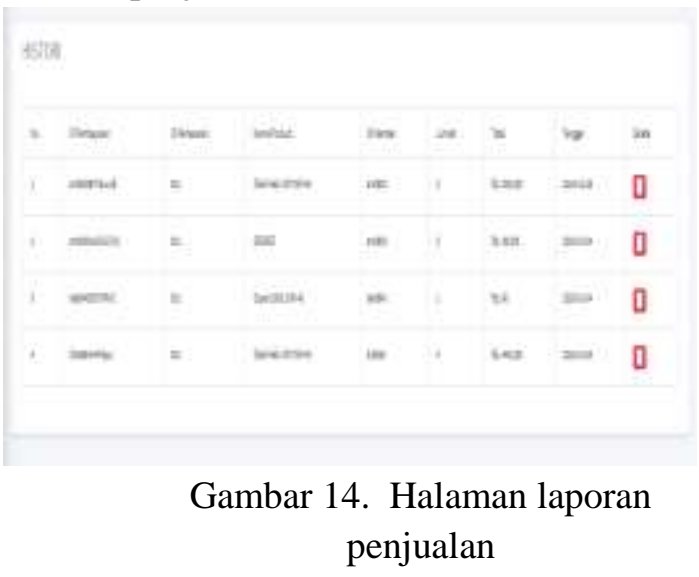

e. Halaman pelanggan sign up

b. Halaman Data Produk 


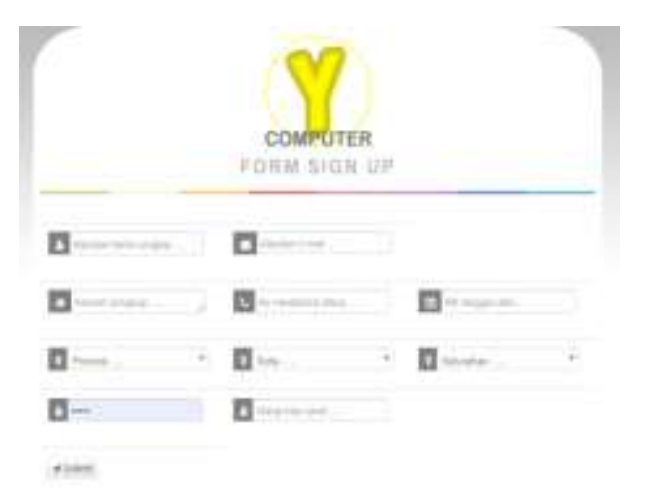

Gambar 15. Pelanggan sign up

f. Halaman pelanggan sign in

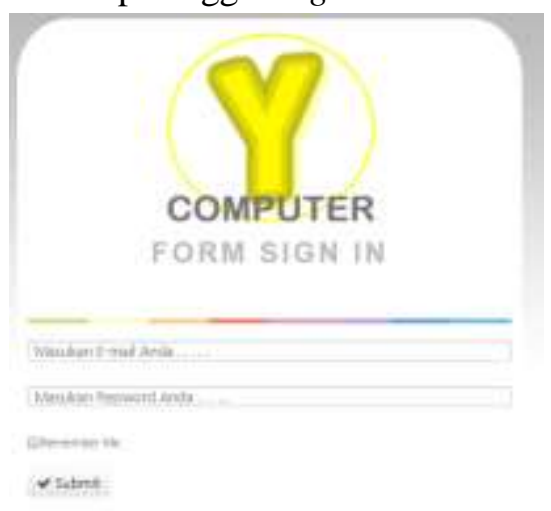

Gambar 16. Pelanggan sign in

g. Halaman pelanggan melakukan upload bukti pembayaran

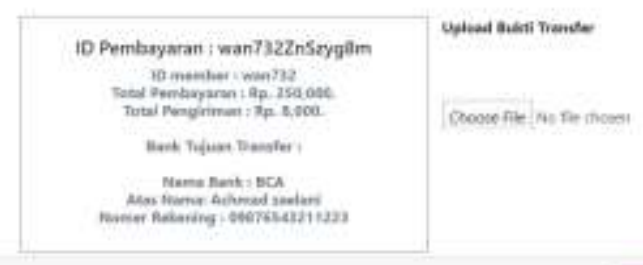

Gambar 17. Pelanggan melakukan pembayaran

\section{Blackbox Testing}

Untuk menguji web sistem informasi penjualan penjualan sparepart komputer berbasis web penulis melakukan penggujian blackbox testing terhadap proses cara pemesanan. Adapun hasil pengujian tersebut bisa dilihat pada tabel1.
Tabel 1 Pengujian Black Box Testing cara

pemesanan

\begin{tabular}{|c|c|c|c|c|c|}
\hline $\begin{array}{c}\mathbf{N} \\
\mathbf{0}\end{array}$ & $\begin{array}{c}\text { Skena } \\
\text { rio } \\
\text { pengu }\end{array}$ & $\begin{array}{l}\text { Test } \\
\text { case }\end{array}$ & $\begin{array}{r}\text { Hasil yat } \\
\text { diharapk }\end{array}$ & $\begin{array}{c}\text { Hasil } \\
\text { pengu } \\
\text { jian }\end{array}$ & $\begin{array}{c}\text { Kesi } \\
\text { mpul } \\
\text { an }\end{array}$ \\
\hline 1 & $\begin{array}{l}\text { Tanpa } \\
\text { melak } \\
\text { ukan } \\
\text { sign in } \\
\text { terlebi } \\
\text { h } \\
\text { dahul } \\
\text { u lalu } \\
\text { melak } \\
\text { ukan } \\
\text { pemes } \\
\text { anan }\end{array}$ & $\begin{array}{l}\text { Pela } \\
\text { ngg } \\
\text { an } \\
\text { lang } \\
\text { sun } \\
\text { g } \\
\text { mel } \\
\text { aku } \\
\text { kan } \\
\text { pem } \\
\text { esan } \\
\text { an } \\
\text { prod } \\
\text { uk }\end{array}$ & $\begin{array}{l}\text { Pelangga } \\
\mathrm{n} \text { tidak } \\
\text { bisa } \\
\text { melakuka } \\
\mathrm{n} \\
\text { pemesan } \\
\text { an dan } \\
\text { muncul } \\
\text { pesan } \\
\text { “Maaf } \\
\text { Silahkan } \\
\text { Melakuk } \\
\text { an Sign } \\
\text { In }\end{array}$ & Sesuai & Valid \\
\hline 2 & $\begin{array}{l}\text { Melak } \\
\text { ukan } \\
\text { sign in } \\
\text { terlebi } \\
\text { h } \\
\text { dahul } \\
\text { u lalu } \\
\text { melak } \\
\text { ukan }\end{array}$ & $\begin{array}{l}\text { Pela } \\
\text { ngg } \\
\text { an } \\
\text { mel } \\
\text { aku } \\
\text { kan } \\
\text { sign } \\
\text { in } \\
\text { den }\end{array}$ & $\begin{array}{l}\text { Pelangga } \\
\mathrm{n} \text { bisa } \\
\text { melakuka } \\
\mathrm{n} \\
\text { pemesan } \\
\text { an }\end{array}$ & Sesuai & Valid \\
\hline
\end{tabular}

\section{KESIMPULAN}

Berdasarkan penelitian yang penulis lakukan kepada Yellow Computer, maka dapat disimpulkan yaitu dengan adanya sistem informasi penjualan berbasis web dapat mempermudah Yellow Computer dalam mengelola data penjualan dibandingkan dengan sistem sebelumnya serta meningkatkan omzet penjualan Yellow Computer dengan cara promosi yang tepat.

\section{REFERENSI}

Anna, A., Nurmalasari, N., \& Yusnita, A. E. (2018). Rancang Bangun Sistem Informasi Akuntansi Penerimaan dan Pengeluaran Kas pada Kantor Camat Pontianak Timur. Jurnal Khatulistiwa Informatika, 6(2), 107-118. 
https://doi.org/10.31294/khatulistiwa.v6i 2.153

Hastanti, R. P., Eka, B., Indah, P., \& Wardati, U. (2015). Sistem Penjualan Berbasis Web ( E-Commerce ) Pada Tata Distro Kabupaten Pacitan, 3(2), 1-9.

Heldiansyah, \& Rahma Indera, A. P. A. dan F. S. V. (2015). Pengembangan Sistem Informasi Penjualan Alat Kesehatan Berbasis Web Pada Pt. Alfin Fanca Prima. Positif, 1(1), 37-45.

Kaafi, \& Syahriani. (2016). Sistem Informasi Penjualan Pakaian Berbasis Web. Konferensi Nasional Ilmu Sosial \&
Teknologi (KNiST), 277-282.

Narindro, L., \& Maya Topani, H. (2017). Perencanaan Bisnis Sistem Informasi Percetakan Online Berbasis Aplikasi Web. JIKA (Jurnal Informatika), 1(2). https://doi.org/10.31000/jika.v1i2.1396

Septarini, R. S., \& Husain, yepry M. (2019). Design Prototype E-Service Untuk Meningkatkan Pelayanan Bisnis Umkm Pada Jenis Usaha Jasa Laundry, 1-8.

Setiawan, I., \& Rostianingsih, S. (2020). Aplikasi Sistem Informasi Administrasi Pada UD . Terang Jaya Abadi. Madah, (031), 5-8. 